\title{
Distribution and ecology of Biatoridium monasteriense J. Lahm ex Körb in Poland
}

\author{
Anna Łubek* \\ Institute of Biology, Jan Kochanowski University in Kielce, Świętokrzyska 15, 25-406 Kielce, Poland
}

\section{Abstract}

A new site of Biatoridium monasteriense was discovered during a lichenological investigation in Białowieża National Park. The paper presents information on the distribution of this species in Poland.

Keywords: Białowieża Forest, Biatoridium, lichens, Poland

\section{Introduction}

Biatoridium monasteriense is a very rare lichen in Poland. It is one of only two known representatives of the genus Biatoridium J. Lahm ex Körb. which have been found in only a few places in Europe. It is characterized by a bright, cream apothecia, a green, minutely areolate thallus, and grows in shady and damp places. Biatoridium monasteriense is very similar to B. delitescens (Arnold) Hafellner. The latter, however, is distinguished by a very bright yellow apothecia and a very thin, almost invisible thallus [1]. This species has not yet been found in Poland, and its nearest site can be found in Germany.

During the lichenological research conducted in Białowieża National Park another site of Biatoridium monasteriense in Poland was found. The paper provides information on the distribution of the species in Poland, based on historical and current data, and its environmental characteristics.

\section{Material and methods}

The data on the occurrence of Biatoridium monasteriense J. Lahm ex Körb. [Biatora monasteriensis (J. Lahm) Müll. Arg., Biatorella monasteriensis (J. Lahm ex Körb.) J. Lahm, B. elegans (Hepp) Reinke, B. resinae sensu Mudd p.p., Lecidea monasteriensis (J. Lahm) Nyl.] in Poland were taken from published literature and from the author's own field research conducted in Białowieża National Park in 2009. The data were divided into two time periods. The first period includes information on

*Email: anna.lubek@ujk.edu.pl

This is an Open Access digital version of the article distributed under the terms of the Creative Commons Attribution 3.0 License (creativecommons.org/licenses/by/3.0/), which permits redistribution, commercial and non-commercial, provided that the article is properly cited. the presence of B. monasteriense in the past, that is until 1990. The second period includes information about the currently existing localities recorded during the last 20 years. Sites of the species are presented on a map of Poland divided into squares in the ATPOL system [2]. In the case of two historical sites the ATPOL square could not be accurately determined, and so the sites are marked with the symbol "?".

A specimen has been deposited in the Herbarium of Jan Kochanowski University (KTC).

\section{Results and discussion}

\section{Distribution in Poland}

In the past the species was known from eight sites (Fig. 1). Two of them do not have an exact location. These are the sites mentioned in the work by Eichler $[3,4]$ ) - in the surroundings of Międzyrzec (probably the ATPOL square Df48) and in the work by Magnusson [5,6]) - in the surroundings of Rybnik in Silesia (probably the ATPOL square Fc69). The next two sites were located in Borecka Forest - the forestry Knieja, forest section No. 4 and near the lake Łękuk (the ATPOL squares Bf03, Bf13; [1,7]). Other sites determined before 1990 were located in the southern part of Poland: the Western Bieszczady Mts - by the Wołosaty stream; (the ATPOL square Gf59; [8]), the Beskid Sląski Mts - Malinowska rock (the ATPOL square Gd13; [9]), the Pogórze Spiskie - by the Piekielnik stream (the ATPOL square Ge41; [10]), and the Gorce Mts - Gorc Kamienicki (the ATPOL square Ge12; [11]).

Currently the species has been found at two sites in the northern and north-eastern part of Poland, i.e. in the Gdańsk Pomerania - N of Wejherowo by the Reda river (the ATPOL square Ac58; [12]), the Północnomazowiecka Lowland - in the Dziektarzewo nature reserve (the ATPOL square Ce61; [13]), Borecka Forest - forestry Lipowo (the ATPOL square Bf13; $[14,15])$ and at two sites in the southern part of Poland in the Western Bieszczady Mts - Wołosate (the ATPOL square Gg70; Kościelniak 2010, unpublished data, see also [16]) and 


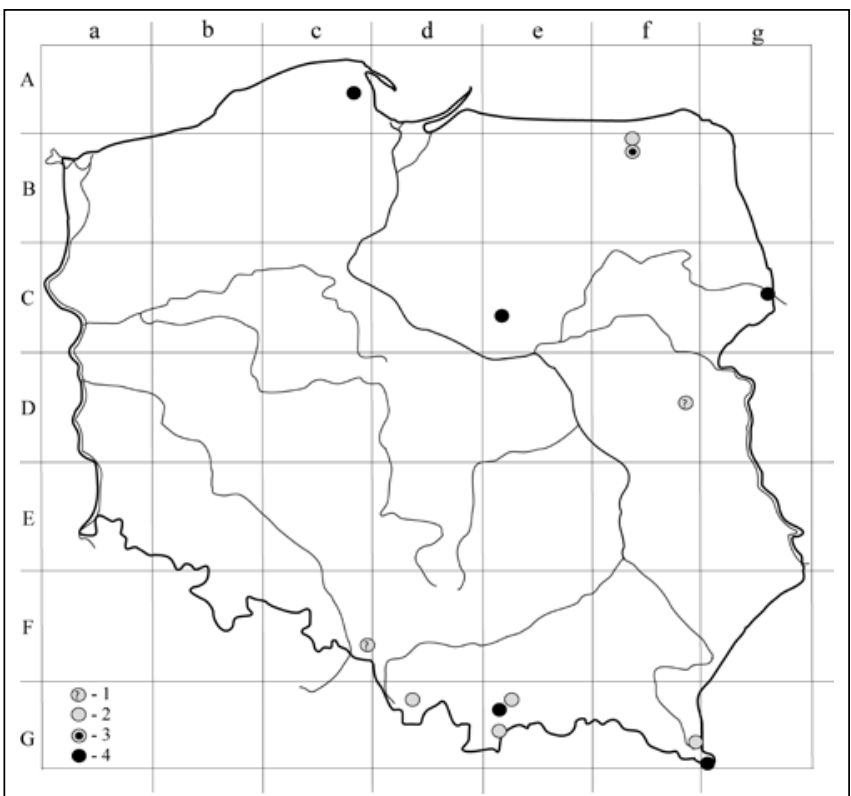

Fig. 1 Distribution of Biatoridium monasteriense J. Lahm ex Körb. in Poland. Site: 1 - historical of possible location; 2 - historical; 3 historical and currently existing; 4 - currently existing.

Gorce Mts - Gorce National Park (five records of the species; the ATPOL square Ge21; [17]).

The new site of the species was found in the eastern part of Poland in Bialowieża National Park.

\section{New location}

Specimen examined: Poland, Białowieża Forest, Białowieża National Park, forest section No. 372, on the bark of Carpinus betulus, 2009.06.24 (the ATPOL square Cg46; KTC). The species was growing in the company of: Arthothelium ruanum, Pyrenula nitida, $P$. nitidella, Opegrapha vermicellifera and $O$. vulgata.

\section{Morphology}

The specimens of Biatoridium monasteriense found in Białowieża National Park are characterized by a very well formed thallus. It is thickly granular, widespread and without clear boundaries. When the thallus is dry it is a green-grey colour when it is wet the colour changes to bright-green. The apothecia are very numerous and are scattered all over the thallus. Young apothecia are stuck slightly into the thallus, the older ones are in the sitting position. Apothecia achieve diameters of 0.3-0.5 mm. Apothecia are pale pink or yellowish when dry or almost colourless and translucent when wet. The discs of the apothecia are flat or slightly convex and are surrounded by a clearly visible thin margin. Under the influence of dampness the discs become convex. The hypothecium in the apothecia is yellowish and approximately $40-80 \mathrm{~nm}$ thick and very convex. The hymenium is colourless and about $60-80 \mathrm{~nm}$ thick. The hypothecium and hymnenium become blue-coloured from J+. Asci in the apothecia are narrowly-clavate and have from 100 to 200 spherical spores of 3-3.5 nm diameter.

\section{European distribution}

The species is widespread in Europe (Fig. 2), but in every place it is a rather rare lichen. It has been found in: Austria [18], Belgium [19], Croatia [20], the Czech Republic [21], Estonia [22], Finland [23], Germany [24], Great Britain and Ireland

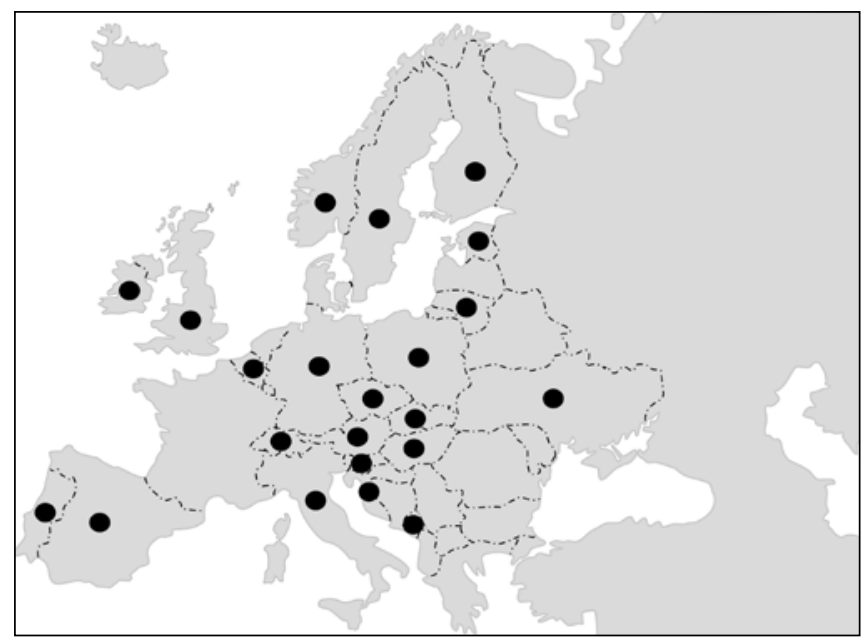

Fig. 2 The occurrence of Biatoridium monasteriense J. Lahm ex Körb. in Europe.

[25], Hungary [26], Italy [27], Lithuania [28], Montenegro [29], Portugal [30], Slovakia [31], Slovenia [32], Spain [33], Sweden and Norway [34], Switzerland [35], and Ukraine [36]. Apart from Europe the species is also known in India [37].

\section{Ecology}

In the foreign literature Biatoridium monasteriense is described as a species which grows in the shade, on base-rich bark of broadleaved trees such as Ulmus glabra, Fraxinus excelsior, Alnus glutinosa, Sambucus nigra, Quercus sp., Tilia sp., or Corylus avellana in sheltered ancient woodland habitats, often in stream valleys. It usually grows in crevices in the bark. On the few Polish sites this species usually grows in damp and shady places, often near streams, on the bark of trees such as Fagus sylvatica, Fraxinus excelsior, Acer pseudoplatanus, Alnus glutinosa, Ulmus glabra and Picea abies. It grows in natural beech, alder, beech-fir or riparian forests. B. monasteriense has been found at different heights above sea level, both in the lowlands and in mountainous terrain (up to $1140 \mathrm{~m}$ a.s.l.).

B. monasteriense appears to be selective for bark chemistry - $\mathrm{pH}$ and nutrient levels and physical bark characteristics - porosity and water absorption. It prefers shade and is moisture-demanding, and therefore it is often found growing along sheltered crevices at the lower parts of the tree trunks.

\section{Threat}

Because of its rarity, this species is considered threatened in many countries. It is Critically Endangered (CR) in Slovakia [38], Endangered (EN) in Great Britain [39], Vulnerable (VU) in the Czech Republic [21] and Austria [40] and Least Concern (LC) in Switzerland [41] and Sweden [42]. In Poland the species is also placed in the category Near Threatened (NT) [43]. Sites of Biatoridium monasteriense are generally situated in well-preserved forest communities. Therefore, it is regarded as an indicator of the ecological continuity of forests in some countries, e.g. in Sweden [44].

Present sites of the species on Polish territory have also been found in forests of natural character. The attachment of the species to habitats associated with old forests, and its occasional occurrence on such sites, shows that it is a highly stenotopic lichen. In the Białowieża National Park, on the site where $B$. monasteriense was found, there are other very rare species, such as Opegrapha vermicellifera, O. viridis, Pyrenula 
nitidella, Chrysothrix candelaris, and Chaenotheca brachypoda. Possibly B. monasteriense, like other stenotopic species, belongs to a group of lichens which are indicators of the ecological continuity of primeval forests. It possesses characteristics of species which are indicators of natural lowland old-growth forest [45], i.e. it is a stenotopic lichen with strict ecological amplitude and occurs only in natural forests. It is advisable to add this species to the list of those which require special care and monitoring research.

\section{Acknowledgments}

I am grateful to Dr. Anna Zalewska (Olsztyn) and Dr. Robert Kościelniak (Kraków) for their valuable assistance in obtaining unpublished data on the species.

\section{References}

1. Hafellner J. On Biatoridium, a resurrected genus of lichenized fungi (Ascomycotina, Lecanorales). Acta Bot Fenn. 1994;150:39-46.

2. Cieśliński S, Fałtynowicz W, editors. Note from editors. In: Atlas of the geographical distribution of lichens in Poland. Kraków: W. Szafer Institute of Botany, Polish Academy of Sciences; 1993. p. 7-8.

3. Eichler B. Spis porostów znalezionych w okolicach Międzyrzeca. Pam Fizjogr. 1886;6:251-268.

4. Motyka J. Porosty (Lichenes). 4.2. Umbilicariaceae, Acarosporaceae, Thelocarpaceae. Flora polska. Rośliny zarodnikowe Polski i ziem ościennych. Warszawa: Polish Scientific Publishers PWN; 1964.

5. Magnusson A. Acarosporaceae und Thelocarpaceae. In: Zahlbruckner A, editor. Dr. L. Rabenhorst's KryptogamenFlora von Deutschland, Oesterreich und der Schweiz. Leipzig: Akademische Verlagsgesellschaft; 1935. p. 1-318. (vol 9 ch. 5 pt 1 ).

6. Tobolewski Z. Wykaz porostów dotychczas stwierdzonych w Polsce. Poznań: Polish Scientific Publishers PWN; 1965. (Prace Komisji Biologicznej. Poznańskie Towarzystwo Przyjaciól Nauk. Wydział Matematyczno - Przyrodniczy; vol 24 pt 3).

7. Zielińska J. Dokumentacja badań flory porostów zlewni Jeziora Łękuk w Puszczy Boreckiej w Nadleśnictwie Borki. Warszawa: Institute of Environmental Protection - National Research Institute; 1989.

8. Glanc K, Tobolewski Z. Porosty Bieszczadów Zachodnich. Poznań: Polish Scientific Publishers PWN; 1960. (Prace Komisji Biologicznej. Poznańskie Towarzystwo Przyjaciól Nauk. Wydział Matematyczno - Przyrodniczy; vol 21 pt 4).

9. Kiszka J. Porosty Beskidu Śląskiego. Roczn Nauk Dydakt WSP. 1967;28:5-91.

10. Kiszka J. Porosty Pogórza Spiskiego. Studia Ośrodka Dokumentacji Fizjograficznej. 1985;13:213-243.

11. Czarnota P, Glanc K, Nowak J. Materiały do bioty porostów Gorców ze zbiorów Herbarium Instituti Botanici Polskiej Akademii Nauk w Krakowie. Fragm Flor Geobot. 2005;12(2):327-370.

12. Kukwa M. New localities of rare and interesting lichens in Gdańsk Pomerania. Part III. Acta Bot Cassub. 2006/2007;6:141-152.

13. Kubiak D. Porosty rezerwatu Dziektarzewo. Parki Nar Rez
Przyr. 2009;28(2):45-55.

14. Zalewska A. Ekologia porostów Puszczy Boreckiej i jej obrzeży. Studium bioróżnorodności [PhD thesis]. Olsztyn: University of Warmia and Mazury in Olsztyn; 2000.

15. Cieśliński S. Atlas rozmieszczenia porostów (Lichenes) w Polsce Północno-Wschodniej. Warszawa: Białowieża Geobotanical Station; 2003. (Phytocoenosis - Supplementum Cartographiae Geobotanicae; vol 15 pt 15).

16. Kiszka J, Kościelniak R. Lobarion lichens as indicators of the primeval forests of the eastern Carpathians: Darwin international workshop honored to the 100-years anniversary of a famous Ukrainian lichenologist Professor Alfred M. Oxner (1898-1973); 1998 May 25-30; Kostrino, Ukraine. In: Kondratyuk SY, Coppins BJ, editors. Kostrino: M.H. Kholodny Institute of Botany; 1998. p. 81-101.

17. Czarnota P. Porosty Gorczańskiego Parku Narodowego. Cześć I. Wykaz i rozmieszczenie gatunków. Parki Nar Rez Przyr. 2000;19(1):3-73.

18. Hafellner J, Türk R. Die lichenisierten Pilze Österreich - eine Checkliste der bisher nachgewiesenen Arten mit Verbreitungsangaben. Stapfia. 2001;76:1-167.

19. Diederich P, Ertz D, Stapper N, Sérusiaux E, van den Broeck $\mathrm{D}$, Ries C. The lichens and lichenicolous fungi of Belgium, Luxembourg and northern France [Internet]. 2010 [cited 2010 Apr 12]; Available from: http://www.lichenology.info

20. Checklist of lichens and lichenicolous fungi of Croatia [Internet]. 2010 [cited 2010 Apr 12]; Available from: http:// www.biologie.uni-hamburg.de/checklists/lichens/europe/ croatia_l.htm

21. Liška J, Palice Z, Slaviková Š. Checklist and red list of lichens of the Czech Republic. Preslia. 2008;80:151-182.

22. Randlane T, Saag A, Suija A. Lichenized, lichenicolous and allied fungi of Estonia [Internet]. 2006 [cited 2010 Apr 12]; Available from: http://www.ut.ee/lichens/fce.html

23. Vitikainen O, Ahti T, Kuusinen M, Lommi S, Ulvinen T. Checklist of lichens and allied fungi of Finland. Helsinki: Botanical Museum - Finish Museum of Natural History; 1997.

24. Wirth V. Die Flechten Baden-Württembergs. 2nd ed. Stuttgart: Ulmer; 1995. (vol 1).

25. Coppins BJ. Checklist of lichens of Great Britain and Ireland. London: British Lichen Society; 2002.

26. Vondrák J, Šoun J, Lőkös L, Khodosovtsev A. Noteworthy lichen-forming and lichenicolous fungi from the Bükk Mts, Hungary. Acta Bot Hung. 2009;51(1):217-230. http:// dx.doi.org/10.1556/ABot.51.2009.1-2.20

27. Nimis PL, Tretiach M. Itinera Adriatica - lichens from the eastern part of the Italian peninsula. Studia Geobot. 1999;18:51-106.

28. Motiejūnaitė J. Checklist of lichens and allied fungi of Lithuania. Botanica Lithuanica. 1999;5(3):251-269.

29. Bilovitz PO, Knežević B, Stešević D, Vitikainen O, Dragićević S, Mayrhofer H. New or otherwise interesting lichenized and lichenicolous fungi from Montenegro. Fritschiana (Graz). 2008;62:1-44.

30. van den Boom PPG, Girlat M. Contribution to the flora of Portugal, lichens and lichenicolous fungi I. Nova Hedw. 1996;63(1-2):145-172.

31. Pišút I, Lackovicová A, Lisická E. A second checklist and bibliography of Slovak lichens. Biologia. 1996;51(3 suppl):1-79.

32. Checklist of lichens and lichenicolous fungi of Slovenia [Internet]. 2010 [cited 2010 Apr 12]; Available from: http:// 
www.biologie.uni-hamburg.de/checklists/lichens/europe/ slovenia_l.htm

33. van den Boom PPG. Some lichens and lichenicolous fungi from Majorca (Spain). Linzer Biol Beitr. 1999;31(2):785-800.

34. Santesson R. The lichens and lichenicolous fungi of Sweden and Norway. Lund: SBT-förlaget; 1993.

35. Checklist of lichens and lichenicolous fungi of Switzerland [Internet]. 2010 [cited 2010 Apr 12]; Available from: http:// www.biologie.uni-hamburg.de/checklists/lichens/europe/ switzerland_l.htm

36. Bielczyk U, Bylińska E, Czarnota P, Czyżewska K, GuzowKrzemińska B, Hachułka M, et al. Contribution to the knowledge of lichens and lichenicolous fungi of Western Ukraine. Polish Bot J. 2005;50(1):39-64.

37. Hariharan G, Balaji P. Checklist of lichens and lichenicolous fungi of Tamil Nadu (India) [Internet]. 2008 [cited 2010 Apr 12]; Available from: http://www.biologie.unihamburg.de/checklists/lichens/asia/india_tamil-nadu_l. htm

38. Pišút I, Guttová A, Lackovičová A, Lisická E. Červený zoznam lišajníkov Slovenska. Ochr Prír. 2001;20 suppl:23-30.
39. Woods RG, Coppins BJ. A conservation evaluation of British lichens. London: British Lichen Society; 2003.

40. Türk R, Hafellner J. Red list of endangered lichens in Austria [Internet]. 1999 [cited 2010 Apr 12]; Available from: http://www.uni-graz.at/ hafell/redlist.htm

41. Scheidegger C, Clerc P. Rote Liste der gefährdeten baumund erdbewohnenden Flechten der Schweiz. Bern: BUWAL; 2002.

42. Gärdenfors U. The 2005 red list of Swedish species. Uppsaala: ArtDatabanken, SLU; 2005.

43. Cieśliński S, Czyżewska K, Fabiszewski J. Czerwona lista porostów wymarłych i zagrożonych w Polsce. Monogr Bot. 2003;91:13-49.

44. Arup U. Indikatorarter och viktiga miljöer. In: Arup U, Ekman S, Kärnefelt I, Mattsson JE, editors. Skyddsvärda lavar i sydvästra Sverige. Lund: SBT Förlaget; 1997. p. 96-103.

45. Czyżewska K, Cieśliński S. Porosty - wskaźniki niżowych lasów puszczańskich w Polsce. Monogr Bot. 2003;91:223-239. 